\title{
Subcutaneous emphysema of the neck, chest, and abdomen as a symptom of colonic diverticular perforation into the retroperitoneum
}

\author{
Dariusz Janczak ${ }^{1,2}$, Agnieszka Ziomek ${ }^{2}$, Tadeusz Dorobisz ${ }^{2}$, Karolina Dorobisz $^{3}$, Dawid Janczak², \\ Wiktor Pawłowski², Mariusz Chabowski ${ }^{1,2}$
}

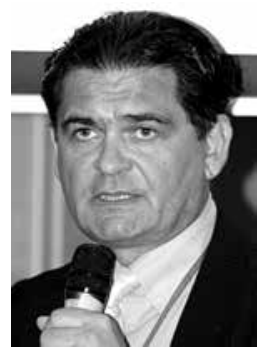

${ }^{1}$ Department of Clinical Proceedings, Faculty of Health Science, Wroclaw Medical University, Wroclaw, Poland

${ }^{2}$ Department of Surgery, $4^{\text {th }}$ Military Teaching Hospital, Wroclaw, Poland

${ }^{3}$ Department of Otolaryngology and Head and Neck Surgery, Wroclaw Medical University, Wroclaw, Poland

Kardiochirurgia i Torakochirurgia Polska 2016; 13 (1): 55-57

\begin{abstract}
We describe a rare case of a patient with colonic diverticular perforation manifested only by subcutaneous emphysema of the neck, chest, and abdomen, as visualized by a computed tomography (CT) scan.

The 76-year-old female patient with a history of internal diseases was urgently admitted to the Clinic of Internal Diseases due to a urinary tract infection. During the hospitalization, further diagnostic procedures were performed due to palpable subcutaneous emphysema of the neck, chest, and abdomen. Computed tomography examination revealed massive intraabdominal, intramuscular, and subcutaneous emphysema. A decision was made to perform exploratory laparotomy; the procedure exposed an inveterate diverticular perforation of the sigmoid-rectal flexure as well as air-inflated retroperitoneal tissue. The perforated colon was resected, and a stoma was formed. On the $15^{\text {th }}$ postoperative day, the patient died due to cardiorespiratory failure.

Although subcutaneous emphysema is a common symptom in everyday medical practice, its etiology remains complex. One should consider this clinical presentation of colonic diverticular perforation, especially in elderly patients in whom the perforation signs may be clinically less marked.

Key words: colonic diverticular perforation, massive subcutaneous emphysema.
\end{abstract}

\section{Introduction}

Colonic diverticula are small mucosal herniations through points of reduced resistance in the muscular wall of the colon. At these locations, arterioles penetrate the colonic wall which is overgrown with fat tissue [1]. Colonic diverticula affect people over 50 years of age and constitute one of the most com-

\section{Streszczenie}

W pracy zaprezentowano rzadki przypadek pacjentki z perforacją uchyłka okrężnicy, której jedynym objawem była masywna rozedma podskórna szyi, śródbrzusza i klatki piersiowej uwidoczniona w badaniu tomografii komputerowej (TK).

Kobieta, 76 lat, z licznymi obciążeniami internistycznymi została przyjęta do Kliniki Chorób Wewnętrznych w trybie pilnym z rozpoznaniem zakażenia dróg moczowych. W trakcie hospitalizacji z powodu wyczuwalnej rozedmy podskórnej obejmującej powłoki szyi, klatki piersiowej i brzucha wykonano poszerzoną diagnostykę. Badanie TK uwidoczniło masywną rozedmę śródbrzuszną oraz rozedmę podskórną powłok ciała i śródmięśniową. Zdecydowano o wykonaniu zwiadowczej laparotomii, podczas której uwidoczniono zastarzałą perforację uchyłka okolicy zagięcia esiczo-odbytniczego oraz rozdęte powietrzem tkanki przestrzeni zaotrzewnowej. Resekowano odcinek jelita z perforacją i wyłoniono stomię. W 15. dobie po operacji pacjentka zmarła z powodu niewydolności krążeniowo-oddechowej.

Chociaż rozedma podskórna jest częstym objawem w praktyce lekarskiej, jej etiologia bywa bardzo różna. Należy zwrócić szczególną uwagę na nietypową prezentację kliniczną perforacji uchyłka okrężnicy, zwłaszcza u starszych pacjentów, u których objawy ogólne są mniej nasilone.

Słowa kluczowe: perforacja uchyłka okrężnicy, masywna rozedma podskórna.

mon human diseases. It is a disease of affluence that commonly occurs in developed countries, but is almost unheard of in developing countries. Diverticula are mainly caused by intestinal motility disorders (mainly those involving the sigmoid colon) and are accompanied by increased intraluminal pressure which causes the muscular tissue to thicken. About $90 \%$ of cases are asymptomatic [2]. A small fraction of patients experi- 
ence strong paroxysmal pain in the left iliac fossa. On palpation, the patient experiences local compressive pain. The main complication of the diverticular disease is diverticulitis, which may result in intestinal wall perforation. Its symptoms, similar to those of acute abdomen, include severe pain, constipation, a positive Blumberg sign, and muscular guarding.

The presence of air in the subcutaneous tissue is called subcutaneous emphysema. This condition develops when pneumothorax or mediastinal emphysema causes the air to penetrate under the skin of the neck or, less frequently, the chest and abdomen [3]. Gastrointestinal perforation as the source of air is casuistic.

\section{Case study}

A 76-year-old female patient with a history of internal diseases was urgently admitted to the Clinic of Internal Diseases due to a diagnosed urinary tract infection. On admission, the patient was in moderate general condition: she was chronically bedridden, and her limbs were deformed

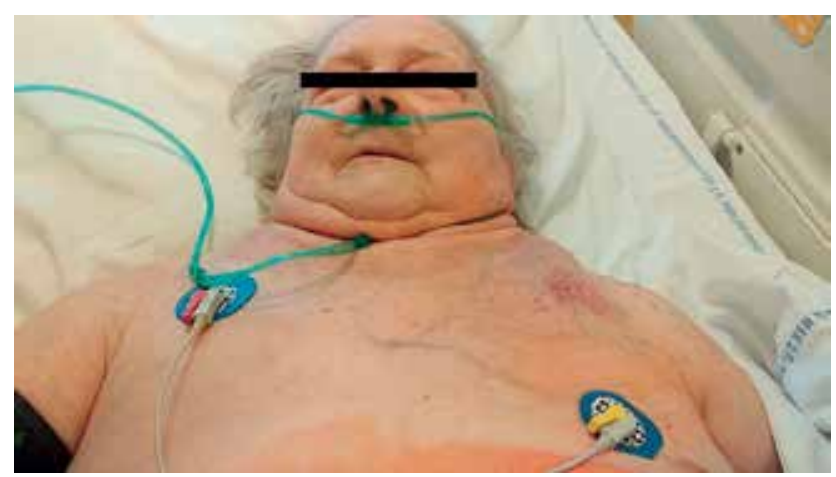

Fig. 1. Clinical manifestation of palpable massive subcutaneous emphysema of the neck, chest, and abdomen
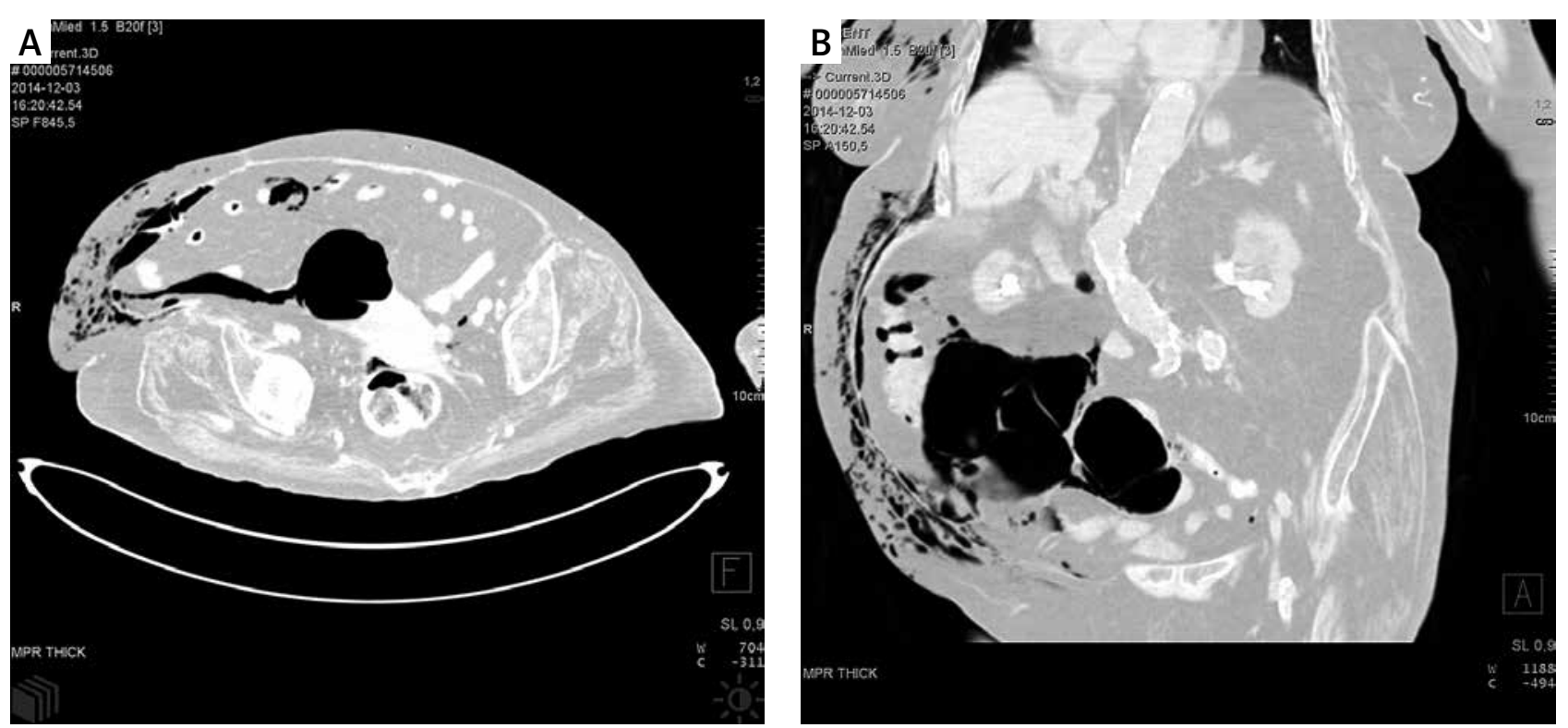

Fig. 2. Abdominal computed tomography scan - massive intra-abdominal emphysema with gas collecting mainly in the right iliac fossa, a large gas sac to the right of the midline $(6 \times 8 \mathrm{~cm}$ in size), massive left-sided subcutaneous emphysema, and right-sided intramuscular emphysema of the chest

due to rheumatoid arthritis (RA); she had tachycardia (HR $140 \mathrm{bpm}$ ) and her blood pressure was RR 110/70 $\mathrm{mmHg}$. On initial examination, the abdomen was soft, non-tender, slightly bloated, without peritoneal signs. Healed postappendectomy scars were visible. The family had noticed a deterioration in communication with the patient on the previous day. The patient denied having dysuria or fever. Laboratory tests showed elevated levels of CRP (158.8) and procalcitonin (0.85), leukocytosis $(21,000)$, and signs of the urinary tract infection. The patient was catheterized, which produced a purulent urine discharge. Enterococcus faecalis (HLAR+) was isolated from the urine. No abnormalities were detected on abdominal ultrasound. During the hospitalization, the patient's condition remained stable. Inflammatory markers were reduced (leukocytes: 8,300, CRP: 84.3, procalcitonin: <0.1). Due to increasing RA symptoms, a comparative X-ray examination of the hip joints was conducted, revealing relatively substantial abdominal subcutaneous and intramuscular emphysema. Due to the absence of clinical signs of pneumothorax, the image was interpreted as the shadow of the diaper. On the following day, palpable subcutaneous emphysema of the abdomen and chest developed, providing an indication for further diagnostics (Fig. 1). Massive left-sided intra-abdominal and subcutaneous emphysema as well as right-sided intramuscular emphysema of the chest were revealed on CT examination. The gas accumulated mostly in the right iliac fossa; a large gas sac ( $6 \times 8 \mathrm{~cm}$ in size) was located to the right of the midline (Fig. 2). On physical examination, the abdomen was soft; the examination revealed no peritoneal signs and strong peristaltic waves. A decision was made to transfer the patient to the surgical ward. Considering the minimal clinical signs of the disease and the CT image, exploratory laparotomy was performed. Retroperitoneal perforation of 
the cecum and ascending colon was revealed. The spherical shape on the CT image turned out to be an air-filled tumor of the colon, formed from the peritoneum. During the procedure, sigmoid colonic diverticular perforation into the retroperitoneum was detected. Therefore, a segment of the sigmoid colon was resected, and a stoma was formed. On the $15^{\text {th }}$ postoperative day, the patient died due to cardiorespiratory failure.

\section{Discussion}

There are many causes for subcutaneous air collection. The most common include pneumothorax, esophageal perforation and other diseases, such as gas gangrene [4]. Gastrointestinal perforation secondary to diverticulitis or toxic megacolon in the course of ulcerative colitis represent extremely rare causes of subcutaneous emphysema [5]. Cases of iatrogenic subcutaneous emphysema caused by endoscopic surgery are more frequent. The relevant literature also describes cases of scrotal emphysema caused by gastrointestinal tract perforation $[6,7]$. It is worth noting that, in this case, the late development of subcutaneous emphysema was the only sign of the inveterate perforation. The patient had not reported any abdominal pain and was admitted to the hospital due to dysuria. No signs of peritonitis were found during the physical examination performed on admission; the abdomen was soft and the peristaltic waves were strong. The consulting surgeon also saw no signs that would indicate an acute abdominal disease. Subcutaneous emphysema is not a specific symptom of intestinal perforation, which is why such manifestation of this disease may cause many diagnostic problems. The diagnostic tool of choice in such cases is usually abdominal CT. In this case, the CT scan revealed intra-abdominal emphysema, which suggested gastrointestinal tract perforation [8]. However, the exact cause of subcutaneous emphysema was only determined during the exploratory laparotomy.

\section{Disclosure}

Authors report no conflict of interest.

\section{References}

1. Kassir R, Abboud K, Dubois J, Baccot S, Debs T, Favre P, Gugenheim J, Gastaldi P, Amor IB, Tiffet O. Perforated diverticulitis of the sigmoid colon causing a subcutaneous emphysema. Int J Surg Case Rep 2014; 5: 1190-1192.

2. Souche R, Bouyabrine H, Navarro F. Subcutaneous emphysema of thorax, neck and face after elective left colectomy: a case report. Int J Surg Case Rep 2013; 4: 489-492.

3. Sivarajah V, Jones C, Pittathankal A. Radiological evidence of subcutaneous emphysema leading to a diagnosis of retroperitoneal perforated diverticulum. Int J Surg Case Rep 2013; 4: 531-533.

4. Agaba EA, Kandel AR, Agaba PO, Wong LS. Subcutaneous emphysema, muscular necrosis, and necrotizing fasciitis: an unusual presentation of perforated sigmoid diverticulitis. South Med J 2010; 103: 350-352.

5. De'Ath HD. Perforation of a sigmoid diverticulum presenting with a pneumoscrotum and surgical emphysema. BMJ Case Rep 2008; doi: 10.1136/ bcr.08.2008.0834.

6. Mirzayan R, Cepkinian V, Asensio JA. Subcutaneous emphysema, pneumomediastinum, pneumothorax, pneumopericardium, and pneumoperitoneum from rectal barotrauma. J Trauma 1996; 41: 1073-1075.

7. Arana-Arri E, Cortés H, Cabriada V, Lekerika N, García-Verdugo A, ShengeliaShapiro L. Giant fecaloma causing perforation of the rectum presented as a subcutaneous emphysema, pneumoperitoneum and pneumomediastinum: a case report. Eur J Emerg Med 2007; 14: 351-353.

8. Marwan K, Farmer KC, Varley C, Chapple KS. Pneumothorax, pneumomediastinum, pneumoperitoneum, pneumoretroperitoneum, and subcutaneous emphysema following diagnostic colonoscopy. Ann R Coll Surg Engl 2007; 89: W20-W21. 